\title{
Equality of Opportunity, Cultural Diversity and Claims for Fairness
}

MitJA SARDOČ ${ }^{1}$

$\approx$ The present paper examines some of the tensions, problems and challenges associated with claims for equality of opportunity (the fairness argument). The introductory part identifies three separate forms of justification for public education, including the argument associated with equality of opportunity. Part II examines in detail two questions that reveal part of the anatomy of equality of opportunity: (1) what an opportunity is, and (2) when individuals' opportunities are equal. This is followed by a presentation of the two basic principles of equality of opportunity: (1) the principle of non-discrimination, and (2) the "levelling the playing field" principle. The next part takes up the multiculturalist hypothesis advanced by minority groups for the accommodation and recognition of cultural diversity. This is followed by the identification of a set of claims comprising the "fairness argument". The last section focuses on the "currency problem" associated with cultural diversity as a form of "unfair disadvantage". Part V examines two of the major shortcomings associated with the multicultural conception of equality of opportunity, while the concluding part discusses some of the questions that must be answered by any conception of equal opportunities.

Keywords: equality of opportunity, opportunity, equality, cultural diversity, the fairness argument, multiculturalism, education 


\section{Enake možnosti, kulturna različnost in zahteve pravičnosti}

MitJA SARDOČ

$\propto$ Prispevek obravnava nekatere izmed napetosti problemov in izzivov, ki so povezani z zahtevo po zagotavljanju enakih možnosti [argument poštenosti]. Uvodni del poudari tri ločene utemeljitve javnega izobraževanja, vključno z utemeljitvijo, ki je povezana z zagotavljanjem enakih možnosti. Drugi del podrobneje obravnava dve vprašanji, ki razkrivata del anatomije enakih možnosti, in sicer i) kar je priložnost in ii) kdaj so priložnosti posameznikov enake. Temu sledi še predstavitev dveh osnovnih načel zagotavljanja enakih možnosti, in sicer i) načelo nediskriminiranja in ii) načelo »izenačitve igralnega polja«. Sledi analiza hipoteze multikulturalizma po pripoznanju kulturne raznolikosti, ki jo zagovarjajo manjšinske skupine. Temu sledi opredelitev sklopa trditev, ki sestavljajo t. i. »argument poštenosti« ter analizo t. i. "problema valute«, ki je povezana $\mathrm{z}$ utemeljitvijo kulturne raznolikosti kot oblike »nepoštene prikrajšanosti«. Peti del obravnava dve glavni pomanjkljivosti, ki sta povezani z multikulturnim pojmovanjem enakih možnosti. Sklepni del identificira nekatera izmed osnovnih vprašanj, na katera mora odgovoriti vsako pojmovanje enakih možnosti.

Ključne besede: : enake možnosti, priložnost, enakost, kulturna različnost, argument poštenosti, multikulturalizem, vzgoja in izobraževanje 


\section{Equality of opportunity: some preliminary considerations ${ }^{2}$}

Over the last few decades, discussions about public education have been centred around the three separate functions that public education carries out in contemporary societies: (1) the identity-related function; (2) the knowledgerelated function, and (3) the status-related function. Each of the three aspects performs a distinctive function. The dominant feature of the first function is largely socio-integrative, as it links public education with the establishment of the "national" character of a population (Anderson, 1983; Gellner, 1983). As Ernest Gellner emphasises, "education is by far his most precious investment, and in effect confers his identity on him" (Gellner, 1983, p. 36), adding that the monopoly over public education has become, "more important than the monopoly of legitimate violence" (ibid., p. 33). The second basic function carried out by public education focuses on its role as an "ideological state apparatus" (Althusser, 2014). As part of this function, its basic role is to reproduce existing relations of production. The central role played here is by "official knowledge". As Michael W. Apple emphasises, [w] hat counts as knowledge, the ways in which it is organized, who is empowered to teach it, what counts as an appropriate display of having learned it, and - just as critically - who is allowed to ask and answer all of these questions are part and parcel of how dominance and subordination are reproduced and altered in this society. There is, then, always a politics of official knowledge, a politics that embodies conflict over what some regard as simply neutral descriptions of the world and others regard as elite conceptions that empower some groups while disempowering others. (Apple, 1993, p. 222)

This function is based on the assumption that public education serves as a primary tool in the reproduction of existing social relations related to the reproduction of an existing social order. The third function of public education focuses on the provision of equal opportunities in the process of competition for advantaged social positions to all individuals irrespective of their social or cultural background, gender, race, creed, national origin, physical and mental constitution, etc. As John Rawls states, those who have the same level of talent and ability and the same willingness to use these gifts should have the same prospects of success regardless of their social class of origin, the class into which they are born and develop until the age of reason. (Rawls, 2001, p. 44)

From the perspective of justice, it is the latter function that is crucial, as the individual's social status and social mobility depend largely on his/her

2 Parts of this paper are based on a couple of papers published in Slovene language (Sardoč 2013a, 2013b). 
success in the process of education. Equal (educational) opportunities - so their advocates argue - are one of the basic mechanisms for a fair distribution of advantaged social positions and the related social mobility. The importance of providing equality of opportunity within public education has therefore achieved a kind of a general consensus among both experts and policy makers (Husén, 1975). In fact, equality of opportunity has been at the very heart of various discussions about public education (Brighouse, 2007, 2010; Howe, 1989; Jencks 1988). This is evidenced by the fact that a key survey on equal educational opportunities (The Equality of Educational Opportunity Study), the so-called "Coleman Report", has been generally accepted - as pointed out by Geoffrey Borman and Maritza Dowling - as the single "most significant research on schooling, which has ever been conducted" (Borman \& Dowling, 2010). Since its publication, the analysis of equality of opportunity - as Torsten Husén pointed out - has been "raised to a higher level of sophistication" (Husén, 1975, p. 18).

As in other scholarly discussions, opinions regarding the role, importance and effects of equality of opportunity remain largely divided. On the one hand, there are those who place the idea of equality of opportunity alongside other classical liberal ideas, such as justice, freedom and tolerance. As Charles Frankel emphasises, equality of opportunity occupies "a central role in the pantheon of modern political ideals" (Frankel, 1971, p. 193). ${ }^{3}$ Nevertheless, the idea of equality of opportunity is far from being either unquestionable or unproblematic. For example, John Rawls defines it as a "difficult and not altogether clear idea" (Rawls, 2001, p. 43). In fact, the only solid assumption that different conceptions of equality of opportunity share, as Richard Arneson points out (2002), is their rejection of fixed social relations, not a rejection of hierarchy itself.

The main aim of the present paper is to identify some of the basic controversies dominating the discussion regarding equality of opportunity. It consists of four sections. Part II examines in detail two questions associated with the anatomy of equal opportunities: (1) what an opportunity is, and (2) when individuals' opportunities are equal. This is followed by a presentation of the two basic principles of equal opportunities: (1) the principle of non-discrimination, and (2) the "levelling the playing field" principle. Part III takes up the multiculturalist invocation of equality of opportunity. The first section presents the standard multiculturalist hypothesis for the accommodation and recognition of cultural diversity. This is followed by an identification of a set of claims composing the "fairness argument". The focus then shifts to the "currency problem"

3 For a historical overview of changes in the concept of equal opportunities, see Gomberg (2007, pp. 2-5) and Husén (1975 (Chapter 1)). 
associated with cultural diversity as a form of "unfair disadvantage". Part V examines two of the major shortcomings associated with the multicultural conception of equality of opportunity, while the concluding part discusses some of the questions that must be answered by any conception of equal opportunities.

\section{The anatomy of equal opportunities}

The basic premise of any conception of equal opportunities is that individuals' opportunities in the process of competing for advantaged social positions should be equal. Despite the clear-cut message of this idea, a basic question arises: When are individuals' opportunities equal? In order to answer this question, it is first necessary to provide an adequate response to the substantive question: "What is an opportunity?". Without further clarification of this concept and its basic characteristics, the question of when individuals' opportunities are equal cannot adequately be addressed. In fact, as Sven Ove Hansson emphasises, discussions on equality of opportunity have often been "hampered by insufficient attention to the very notion of opportunity itself" (Hansson, 2004, p. 315). Any discussion regarding equality of opportunity therefore needs to address two separate - but interrelated - questions: (1) What is an opportunity? (substantive question), and (2) When are individuals' opportunities equal? (referential question) ${ }^{4}$

\section{What is an opportunity?}

Any conception of equal opportunities, as Peter Westen points out, consists of four basic elements: (1) agent or agents of equal opportunities, (2) objective or objectives to which equal opportunities are directed, (3) the relationship between the agent and the objective of equal opportunities, and (4) obstacles to the realisation of equal opportunities (Westen, 1997, pp. 837-838). The first element primarily brings together the individuals who are entitled to equal treatment, which implies - at least formally - the same conditions. The second aspect, as Peter Westen emphasises, defines the objective of the opportunities, which can be "a job, or an education, or medical care, or a political office, or land to settle, or housing, or a financial investment, or a military promotion, or a life of 'culture', or the development of natural ability or whatever" (ibid., 1997,

4 This distinction is an invaluable tool for identifying differences between various conceptions of equal opportunities. For example, the difference between egalitarian and multicultural conceptions primarily revolves around the substantive question (What is an "opportunity"?), whereas the difference between egalitarian and libertarian conceptions of equal opportunities revolves around the referential question (When are individuals' opportunities equal?). 
p. 838). The third element (the relationship between the agent and the objective of opportunities) is not yet a guarantee that the objective of equal opportunities will be achieved.

The concept of opportunity may therefore be defined in two separate ways: (1) as the absence of obstacles to the attainment of a particular objective (negative justification) and (2) as the ability of an individual to attain a particular goal using his or her efforts (positive justification). An opportunity, as Peter Westen states, "is a chance of an agent $\mathrm{X}$, to choose to attain a goal, $\mathrm{Y}$, Z without the hindrance of obstacle Z" (Westen, 1985, p. 849) or - as Alan H. Goldman argues - "the lack of some obstacle or obstacles to the attainment of some goal(s) or benefit(s)" (Goldman, 1987, p. 88). ${ }^{5}$ Having an opportunity, as Brian Barry claims, means that "there is some course of action lying within my power such that it will lead, if I choose to take it, to my doing or obtaining the thing in question" (Barry, 2005, p. 37). At the same time, opportunity has also been closely linked to the issue of the risk an individual is exposed to when aiming to achieve a particular goal. In fact, as John Roemer emphasises, the individual is actually "responsible for turning that access into actual advantage by the application of effort" (Roemer, 1998, p. 24). If an individual is responsible for the outcome of the process of competing for advantaged social positions, it is therefore necessary to ensure that only those factors an individual may be responsible for should be taken into account. This is consistent with the "control principle", as articulated by Thomas Nagel (Nagel, 1979). So: When are individuals' opportunities equal?

\section{Equality of opportunity}

As a form of "fair competition among individuals for unequal positions in society" (Fishkin, 1983, p. 1), the idea of equality of opportunity is composed of two separate and allegedly incompatible principles: (1) the principle of nondiscrimination, and (2) the principle of levelling the playing field.

\section{Equality of opportunity and non-discrimination}

The principle of non-discrimination gives every individual equal access to advanced social positions, irrespective of any morally arbitrary factors such as gender, social and cultural background, religion, national origin, physical and mental constitution, etc. In this regard, as Lesley A. Jacob points out,

5 For a detailed presentation of the different dimensions of the concept of opportunity (e.g., openness), see Hansson (2004). 
at the very centre of understanding equal opportunities lies a concept that in competitive procedures designed for the allocation of scarce resources and the distribution of the benefits and burdens of social life, those procedures should be governed by criteria that are relevant to the particular goods at stake in the competition and not by irrelevant considerations such as race, religion, class, gender, disability, sexual orientation, ethnicity, or other factors that may hinder some of the competitors' opportunities at success. (Jacobs, 2004, p. 10)

The principle of non-discrimination therefore ensures that the set of potential candidates includes "all individuals who possess the attributes relevant for the performance of the duties of the position in question, [...] and that an individual's possible occupancy of the position be judged only with respect to those relevant attributes" (Roemer, 1998, p. 1). By choosing candidates exclusively on the basis of merit, as George Sher argues, we abstract from all facts about the applicants except their ability to perform well at the relevant tasks. By thus concentrating on their ability to perform, we treat them as agents whose purposeful acts are capable of making a difference in the world ... [S] electing by merit is a way of taking seriously the potential agency of both the successful and the unsuccessful applicants. (Sher, 1988, pp. 119-120)

According to this interpretation, as James Fishkin emphasises, "the assignment of persons to unequal positions according to a fair competition" (Fishkin, 1983, p. 6) is fulfilled as long as three basic conditions are met:

(1) each individual should have equal access to the process of competition for advantaged social positions;

(2) the rules are (a) the same for everyone, (b) known in advance, and (c) connected to the process of competition for advantaged social positions (e.g., carrying out a particular task or performing a job); the best/most qualified candidate wins. ${ }^{6}$

6 The difference between libertarian and egalitarian conceptions of equal opportunities also concerns the validity of the underlying assumptions of the idea of equal opportunities, i.e., that "the best candidate always gets the job". For advocates of the libertarian conception, this principle is absolute: the best candidate always has priority over everyone else. In contrast, for advocates of egalitarian conceptions of equality of opportunity, this principle is applicable only under certain conditions. The best candidate has priority only in cases where all individuals have fair access to qualifications. For the former, fairness of access is satisfied as soon as all individuals have access to qualifications, whereas for the latter, equality of access is genuine once all individuals who compete for an advantaged social position face (at least approximately) the same obstacles. For a detailed comparison of the different conceptions of equal opportunities, see Cavanagh (2002), Squires (2006, pp. 473-477) and Swift (2001). 


\section{Equality of opportunity and compensation for inequality}

The basic objective of the second principle associated with the idea of equality of opportunity (the "levelling the playing field" principle) is to neutralise, reduce, mitigate or even eliminate both the potential benefits of those who might be in an advantaged position as well as the potential barriers to those who might be disadvantaged. In an egalitarian interpretation, equal opportunities should enable any individual, irrespective of any morally arbitrary factors, to achieve a fair starting point in the process of competing for advantaged social positions, as it would be both unjust and unfair, as Larry Temkin points out, to have a situation "when one person is worse off than another through no fault or choice of her own" (Temkin, 1993, p. 13).?

This principle therefore has two separate objectives, which are connected with ensuring the fairness of the non-discrimination principle: (1) the negative objective, and (2) the positive objective. On the one hand, the levelling the playing field principle aims to neutralise, reduce, mitigate or eliminate potential benefits of those individuals who are in a better or privileged position, as well as the potential barriers of those who are - one way or another - disadvantaged; on the other hand, the positive objective associated with the levelling the playing field principle ensures that any individual - regardless of morally arbitrary factors such as gender, race, religion, socioeconomic status, etc. - achieves a fair starting point in the process of competition for advanced social positions. According to this interpretation, as T. M. Scanlon states, inequality should "not disrupt the fairness of on-going competition" (Scanlon, 2003, p. 205).

Moreover, the ideal of equal opportunities needs to distinguish between two of its basic elements: (1) the political element, and (2) the social element. Providing access based on the principle of non-discrimination is part of the "political" element of civic equality, while the compensation programmes we associate with the principle of levelling the playing field are part of the "social" element of civic equality. The political element of equal opportunities is negative, as it does not require any material or financial resources from wider society for its provision. In this sense, its value lies in the absence of formal obstacles, e.g., non-discrimination. Unlike the political or formal element of equality of opportunity, where the basic criterion is that careers are open to talent, the

7 The relationship between the two principles of equal opportunities remains open here. Are the principle of non-discrimination and that of levelling the playing field overlapping, complementary, in tension with each other, or even mutually exclusive? In any case, the relationship between the two principles cannot be thought of as a "weak" or "robust" ideal of equality of opportunity, but as two separate principles, given the fact that the non-discrimination principle deals with the issue of universal access, while the levelling the playing field principle ensures fair access to the process of competition for advanced social positions. 
"social" element of equal opportunities is associated with redistribution and various compensatory programmes. Fair equality of opportunity, as Rawls emphasises, "is said to require not merely that public offices and social positions be open in the formal sense, but that all should have a fair chance to attain them" (Rawls, 2001, p. 43).

The compensatory programmes most commonly associated with fair equality of opportunity are usually justified with two separate arguments: (1) the argument regarding initial positions (the equidistance argument), and (2) the argument regarding the results of a process of advantaged social positions (the equivalence argument). The first argument is essentially a classical argument associated with a broadly liberal conception of equality of opportunity. Given the fact that individuals' initial positions are unequal, compensatory programmes are primarily aimed at the reduction of initial inequality or at equalising the initial conditions associated with equidistance. The second argument associated with compensatory programmes is primarily focused on the compensation for inequality that arises out of the process of competition for advanced social positions. The first group of compensatory programmes is justified by the arbitrary nature of moral criteria for selection, e.g., talent, while the second group aims to reduce, neutralise, mitigate or eliminate inequalities arising from the process of competing for advantaged social positions. Whereas the principle of non-discrimination ensures that morally arbitrary factors have no impact on or do not limit individuals in the process of competing for advanced social positions, the levelling the playing field principle aims to ensure fair conditions for the implementation of the non-discrimination principle. However, things are further complicated with the introduction of multiculturalist claims for the accommodation and recognition of cultural diversity, which are premised on compensating for inequality arising out of cultural diversity.

\section{Equality of opportunity and cultural diversity}

\section{The standard multicultural hypothesis}

Over the last two decades, advocates of multiculturalism have successfully challenged the liberal orthodoxy in its three core assumptions associated with civic equality: (1) that (national) cultures are largely homogeneous; (2) that culture is irrelevant in considerations of the justice of the basic institutional framework of a plurally diverse polity; and (3) that equal treatment and civic equality are coextensive. However, despite a new sensitivity towards considerations of cultural diversity, advocates of multiculturalism have largely ignored a 
number of tensions, problems and challenges stemming from their invocation of equality of opportunity as the basis for the recognition and accommodation of diversity. Two basic dimensions neglected by the advocates of multiculturalism can be identified here: (1) the distributive specification of accommodation (how accommodation is to be carried out); and (2) the agent-relative specification of accommodation (who is the primary target of accommodation). As Bhikhu Parekh emphasises, [...] the concept of equal opportunity [...] needs to be interpreted in a culturally sensitive manner. Opportunity is a subjectdependent concept in the sense that a facility, or resource, or a course of action is only a mute and passive possibility for an individual if she lacks the capacity, the cultural disposition or the necessary cultural background to take advantage of it. (Parekh, 200o, p. 241)

At the same time, the standard liberal view also entails a normative commitment to equal civic respect for diversity, i.e., respect for different conceptions of the good that citizens, as free and equal members of a polity, might hold and that arise from their exercising their basic rights. Part of this commitment is the acknowledgement of individuals' different conceptions of the good, including values, ideals and other doctrinal beliefs. The fact of reasonable pluralism, writes Rawls, refers to circumstances "that reflect the fact that in a modern democratic society citizens affirm different, and indeed incommensurable and irreconcilable, though reasonable, comprehensive doctrines in the light of which they understand their conceptions of the good" (Rawls, 2001, p. 84). The commitment to equal civic respect for diversity presupposes that all citizens within a particular political community should treated as equals, regardless of their ascriptive or conscience-based characteristics, such as race, class, sex, language, religion or any other differentiating characteristic (the requirement of equal consideration).

To summarise: the standard liberal conception of civic equality and its commitment to equality of opportunity can be subsumed under the assertion that equal opportunities associated with the uniform treatment approach are a sufficient requirement of justice. In this interpretation, equal treatment and civic equality are coextensive. As Brian Barry points out, "justice is guaranteed by equal opportunities" (Barry, 2001, p. 32). In this respect, Nils Holtug claims that "if a certain rule applies equally to everyone and gives them identical choice sets, then people have equal opportunities" (Holtug, 2008, p. 84).

Nevertheless, advocates of multiculturalism have maintained that standard conceptions of citizenship are either insensitive towards differences stemming from individuals' cultural identity or outright discriminatory and oppressive. The standard multiculturalist position is based on a number of interrelated claims over the recognition and accommodation of cultural diversity: (1) that 
national minorities, immigrants and indigenous peoples have a legitimate interest in a secure and stable cultural context; (2) that claims for accommodation of cultural diversity are based on justice; and (3) that group rights are the most viable means to assist non-dominant minority groups in their claims for the recognition and accommodation of their cultural differences.

As proponents of multiculturalism have argued (e.g., Kymlicka, 1995; Modood, 2007; Parekh 2000), neither the expansion of status nor the expansion of entitlement associated with the classical liberal egalitarian conception of civic equality has been sufficiently inclusive in confronting claims for the recognition and accommodation of cultural diversity. As they have emphasised, the liberal egalitarian conception of civic equality and its uniform treatment approach towards cultural diversity is insensitive to the claims of minority groups for recognition and accommodation of their cultural differences, as it (1) fails to recognise the legitimate interest of national minorities, immigrants and indigenous peoples in a stable cultural context, (2) lacks the means to compensate adequately for individuals' unequal circumstances, and (relatedly) (3) insufficiently protect the interests of culturally disadvantaged minority groups.

This leads to the assertion that members of non-dominant minority groups are undeservedly disadvantaged in terms of access to a stable and secure cultural environment, which is instrumental for the cultivation of a "context of choice" (the context of choice requirement). One of the main devices used to substantiate claims for the accommodation and recognition of diversity has been built on the idea of fairness. Multiculturalist claims for the accommodation of diversity have been argued largely as compensation for the underserved disadvantages of members of minorities or of immigrants, and have rested on a specific form of argument based on fairness, i.e., "the fairness argument".

\section{The fairness argument}

The standard conception of fair equality of opportunity is therefore based on a set of (interconnected) commitments that are intertwined with one another in the construction of an argument that would legitimate the compensation for individuals' unequal initial positions within the process of competition for advantaged social positions:

(c1) an advantaged social position is to be granted to the best candidate (the assumption of a meritocracy-based conception of excellence);

(c2) the distribution of an advantaged social position according to merit is mutually beneficial to both the winner and the loser (the assumption of mutual advantage); 
(c3) the process of competition for advantaged social positions should only take into account those aspects of an individual's characteristics that are the result of his or her effort or choices, and not those factors for which $\mathrm{s} /$ he has no merit or is not responsible (the voluntaristic assumption of the nature of the currency of equality);

(c4) the individual is solely responsible for the outcome of the process of competing for an advantaged social position and the associated transformation of an opportunity into an advantage (the assumption of the instrumental nature of transitivity);

(c5) the rules of competition should be associated exclusively with the performance of tasks associated with the process of competition for advantaged social positions (the assumption of the excellence of the process of competition for advantaged social positions);

(c6) inequality arising from the process of competition for advantaged social positions is legitimate insofar as access to the process of competition is open (the assumption of the legitimacy of resulting inequality);

(c7) the result of the process of competition for advantaged social positions is just as fair as the process of competition is fair (the assumption of the fairness of the process of competition for advantaged social positions);

(c8) differences between individuals that are independent of individuals' choices should be neutralised and the undeserved disadvantages (somehow) compensated for (the assumption of the equality of the process of competition).

The validity of any conception of equal opportunities that claims to be fair therefore depends on a number of interconnected assumptions, as the basic challenge of equal opportunities is therefore how to ensure that competition for advantaged social positions is fair, and that inequalities resulting from the process of competition are legitimate. This assertion opens up a range of separate questions that any conception of equal opportunities must answer.

\section{The nature of cultural diversity and the "currency problem"}

Among the most important aspects distinguishing different conceptions of equality of opportunity is the very nature of cultural diversity and the forms of potential inequality associated with it: (1) those forms of inequality that are beyond the individual's will (the involuntary aspect of inequality), and (2) those forms of inequality that are part of the individual's choices. The distinction of factors that should be counted among individuals' circumstances and those 
that can be included within the category of individuals' choices is one of the basic theoretical foundations of egalitarian liberalism, as it distinguishes between different conceptions of equality and equal educational opportunities, distinguished primarily by two separate disagreements: (1) "which aspects of individual behavior are beyond one's control and can be attributed to the effect of circumstances", and (2) "whether the same conditions should be provided in part or in its entirety" (Roemer, 1998).

While there are a number of different versions of the fairness argument, they all share a common ideal, as Samuel Scheffler argues, i.e., "inequalities in the advantages that people enjoy are acceptable if they derive from the choices that people have voluntarily made, but that inequalities deriving from unchosen features of people's circumstances are unjust" (Scheffler, 2003, p. 5). This idea, as Shlomi Segall emphasises, is based on the assumption that it is "unfair for one person to be worse off than another due to reasons beyond her control" (Segall, 2008, p. 10). In this interpretation, as Andrew Mason points out, a person can legitimately be required "to bear the costs (or allowed to enjoy the benefits) of those consequences of her behavior the production of which lies within her control but not those the production of which lies beyond it" (Mason, 2001, p. 763). A basic problem that arises here is to determine "which factors should be counted among people's circumstances and which should be subsumed within the category of choice" (Scheffler, 2005, p. 6).

The fundamental question therefore revolves around the distinction between two normative sources of diversity: (1) chance-based diversity, and (2) choice-based diversity. The former is a matter of chance or circumstance, i.e., the unchosen natural and social conditions associated with one's identity, while the latter is a matter of individual choice. As Will Kymlicka firmly points out, "[t]he distinction between choices and circumstances is in fact absolutely central to the liberal project” (Kymlicka, 1989, p. 186). Multiculturalist claims for equality of opportunity emphasise that cultural diversity needs to be compensated for as a matter of fairness. They substantiate this claim with the assertion that cultural diversity of non-dominant minority groups qualifies as a form of "unfair disadvantage" compared to members of the majority culture. Given the fact that this is a central controversy between liberal and multiculturalist conceptions of equal opportunities, it needs further clarification.

\section{Objections to multiculturalist claims for fairness}

Both the fairness argument and the classification of cultural diversity as a form of "unfair disadvantage" have been severely criticised by advocates of 
egalitarian liberalism. Two prevailing objections have been advanced: (1) that a differentiated conception of civic equality is inconsistent with an egalitarian conception of citizenship as free and equal membership in a polity (the civic equality objection), and (2) that cultural differences cannot be equated with disadvantages stemming from brute bad luck, e.g., a handicap (the non-equivalence objection).

The civic equality objection revolves around the criticism that multiculturalist claims for both recognition and accommodation of cultural differences leads to a de-universalisation of civic equality. The multiculturalist conception of civic equality includes - in some interpretations - a decisive rejection of citizenship as free and equal membership in a polity. In particular, the politics of difference and the conceptions of citizenship that go beyond a conception of civic equality based on the uniform treatment approach, e.g., the conception of differentiated citizenship (Young, 1990) and the conception of multicultural citizenship (Kymlicka, 1995), are inconsistent with a conception of civic equality that grants each and every member of a polity an equal set of entitlements. While advocates of the politics of difference claim that differentiated rights are a corrective to the uniform treatment approach, its critics decisively argue that this move is a significant departure from a conception of citizenship as free and equal membership in a polity.

The second set of objections revolves around the characterisation of cultural diversity as "unfair disadvantage". As Brian Barry emphasises in Culture and Equality, A disability - for example, a lack of physical mobility due to injury or disease - supports a strong prima facie claim to compensation because it limits the opportunity to engage in activities that others are able to engage in. In contrast, the effect of some distinctive belief or preference is to bring about a certain pattern of choices from among the set of opportunities that are available to all who are similarly placed physically or financially. The position of somebody who is unable to drive a car as a result of some physical disability is totally different from that of somebody who is unable to drive a car because doing so would be contrary to the tenets of his or her religion. (Barry, 2001, pp. 36-37)

In this interpretation, equating the two forms of diversity is both logically unacceptable and morally wrong. It turns out to be logically unacceptable because we cannot equate a dietary limit to eating foods that include gluten with the religious observation of not eating foods containing gluten. By equating a chance-based form of diversity with a choice-based form of diversity we commit the fallacy of equivalence. In fact, this equation is morally wrong as it is premised on the non-voluntaristic nature of cultural diversity. This observation emphasises the fact that disability and cultural diversity are not equivalent, 
as well as the fact that the liberal conception of civic equality and its model of citizenship as a political conception of the person is premised on the voluntarist understanding of religious and other forms of conscience-based diversity. Nevertheless, an interesting trend can be discerned in controversies over cultural diversity. On the one hand, there has been little disagreement over the centrality of cultural diversity in contemporary discussions of multiculturalism: it seems that both liberalism and multiculturalism share the assumption that inequalities in the advantages people share are acceptable if they result from individuals' deliberate choices, whereas inequalities arising from individuals' unchosen circumstances and conditions are unjust. On the other hand, despite the convergence of opinion on the injustice of inequalities that stem from individuals' circumstances, it remains of crucial importance to determine which aspects can be subsumed under chance-based diversity and which under choice-based diversity.

\section{Conclusion: the paradox(es) of equal opportunity}

Disagreements over the fundamental principles associated with equality of opportunity, criticism of the inefficiency of policies and strategies aiming to ensure a fair process of competition for advantaged social positions, as well as the various objections regarding its alleged unfairness, open a number of questions that need to be answered by any conception, e.g., motivational questions (Why should individuals' opportunities be equalised?); procedural questions (What are the principled foundations of any process claiming to be based on equal opportunities?); genealogical questions (What is a fair starting position to compete for advantaged social positions?); substantive questions (What are the criteria for equalising individuals' prospects?); taxonomic questions (What type of disadvantage is eligible for compensation?); compensatory questions (How should the process of equalising opportunities be carried out?), etc. Furthermore, without clarifying a number of variables associated with these questions, e.g., opportunity, equality, non-discrimination, obstacles, fairness, responsibility, chance, choice, excellence, deservedness, effort, talent, merit, inequality, etc., the idea of equal opportunities remains - as Andrew Mason eloquently puts it - simply a "radically contradictory [...] piece of political rhetoric" (Mason, 2006, p. 1). As it turns out, providing an answer to any of these questions becomes part of the problem and not the solution. 


\section{References}

Arneson, R. (2002). Equality of Opportunity. Stanford Encyclopaedia of Philosophy. Retrieved 31.3.2014 from http://plato.stanford.edu/entries/equal-opportunity.

Barry, B. (2001). Culture and Equality. Cambridge: Polity Press.

Barry, B. (2005). Why Social Justice Matters. Cambridge: Polity Press.

Bowie, N. E. (Ed.) (1988). Equal Opportunity. Boulder, CO: Westview Press.

Cavanagh, M. (2002). Against Equality of Opportunity. Oxford: Oxford University Press.

Clayton, M. (2001). Rawls and Natural Aristocracy, Croatian Journal of Philosophy, 1(3), 239-259.

Fishkin, J. (1983). Justice, Equal Opportunity, and the Family. New Haven: Yale University Press.

Frankel, C. (1971). Equality of Opportunity, Ethics, 81(3), 191-211.

Friedman, M., \& Friedman, R. (1980). Free to Choose: A Personal Statement. London: Harcourt Brace Jovanovich.

Goldman, A. (1987). The Justification of Equal Opportunity, Social Philosophy and Policy, 5(1), 88-103.

Hansson, S. O. (2004). What are Opportunities and Why Should They be Equal, Social Choice and Welfare, 22(2), 305-316.

Holtug, N. (2008). Equality and Difference-Blind Rights. In N. Holtug, K. Lippert-Rasmussen, \& S. Laegaard (Eds.), Nationalism and Multiculturalism in a World of Immigration (pp. 81-118). New York: Palgrave Macmillan.

Holtug, N., Lippert-Rasmussen, K., \& Laegaard, S. (Eds.) (2008). Nationalism and Multiculturalism in a World of Immigration. New York: Palgrave Macmillan.

Jacobs, L. A. (2004). Pursuing Equal Opportunities: The Theory and Practice of Egalitarian Justice.

Cambridge: Cambridge University Press.

Kymlicka, W. (1989). Liberalism, Community and Culture. Oxford: Clarendon Press.

Kymlicka, W. (1995). Multicultural Citizenship: A Liberal Theory of Minority Rights. Oxford: Oxford

University Press.

Kymlicka, W., \& Banting, K. (Eds.) (2006). Multiculturalism and the Welfare State. Oxford: Oxford University Press.

Lukšič Hacin, M., \& Toplak, K. (2012). Teoretizacija multikulturalizma in etnične ekonomije v luči ohranjanja kulturne dediščine med migranti, Dve domovini, (35), 107-117.

Mason, A. (2006). Levelling the Playing Field. Oxford: Oxford University Press.

Modood, T. (2007). Multiculturalism: A Civic Perspective. Cambridge: Polity Press.

Nagel, T. (1979). Mortal Questions. Cambridge: Cambridge University Press.

Parekh, B. (200o). Rethinking Multiculturalism: Cultural Diversity and Political Theory. New York: Palgrave.

Pojman, L. P., \& Westmoreland, R. (Eds.) (1997). Equality: Selected Readings. Oxford: Oxford University Press.

Rawls, J. (1971). A Theory of Justice. Cambridge, Mass.: Harvard University Press. 
Rawls, J. (2001). Justice as Fairness: A Restatement. Cambridge, Mass.: Belknap Harvard.

Roemer, J. E. (1998). Equality of Opportunity. Cambridge, Mass.: Harvard University Press.

Sardoč, M. (2013a). Enake [izobraževalne] možnosti in družbena neenakost, Sodobna pedagogika, $64(2), 48-62$.

Sardoč, M. (2013b). Anatomija enakih možnosti, Šolsko polje, XXIV(5/6), 145- 159.

Scanlon, T. M. (2003). The Difficulty of Tolerance. Cambridge: Cambridge University Press.

Schaar, H. J. (1997 [1967]). Equality of Opportunity, and Beyond. In L. P. Pojman \& R. Westmoreland (Eds.), Equality: Selected Readings (pp. 137-147). Oxford: Oxford University Press.

Scheffler, S. (2003). What is Egalitarianism? Philosophy and Public Affairs, 31(1), 5-39.

Scheffler, S. (2005). Choice, Circumstance, and the Value of Equality? Politics, Philosophy and

Economics, 4(5), 5-28.

Segall, S. (2008). Health, Luck and Justice. Princeton: Princeton University Press.

Sher, G. (1988). Qualifications, Fairness, and Desert. In N. E. Bowie (Ed.), Equal Opportunity (pp.

113-127). Boulder, CO: Westview Press.

Squires, J. (2006). Equality and Difference. In J. S. Dryzek, B. Honig \& A. Phillips (Eds.), The Oxford Handbook of Political Theory (pp. 470-487). Oxford: Oxford University Press.

Swift, A. (2001). Political Philosophy: A Beginner's Guide for Students and Politicians. Cambridge:

Polity Press.

Temkin, L. S. (1993). Inequality. Oxford: Oxford University Press.

Westen, P. (1997 [1985]). The Concept of Equal Opportunity. In L. P. Pojman \& R. Westmoreland

(Eds.), Equality: Selected Readings (pp. 158-167). Oxford: Oxford University Press.

\section{Biographical note}

MitJA SARDoč $(\mathrm{PhD})$ is a researcher at the Educational Research Institute in Ljubljana (Slovenia) where he is member of the 'Social Contract in the 21st Century' research programme. He is author of several scholarly articles and editor of a number of journal special issues on citizenship education, multiculturalism, toleration, equal opportunities and patriotism. He is Managing Editor of Theory and Research in Education [http://tre.sagepub.com/] and member of the editorial board of Educational Philosophy and Theory and the Open Review of Educational Research. He edited two books published by Wiley (Citizenship, Inclusion and Democracy and Toleration, Respect and Recognition in Education). $\mathrm{He}$ is also a contributing author to the SAGE Encyclopedia of Educational Theory and Philosophy. He is editor-in-chief of The Handbook of Patriotism [http://refworks.springer.com/Patriotism] that is to be published by Springer in 2017. 